Article

\title{
Aqueous Arsenic Speciation with Hydrogeochemical Modeling and Correlation with Fluorine in Groundwater in a Semiarid Region of Mexico
}

\author{
Jennifer Ortiz Letechipia ${ }^{1}\left(\mathbb{D}\right.$, Julián González-Trinidad $1, *\left(\mathbb{0}\right.$, Hugo Enrique Júnez-Ferreira ${ }^{1, *}(\mathbb{D}$, \\ Carlos Bautista-Capetillo ${ }^{1}\left(\mathbb{D}\right.$, Cruz Octavio Robles-Rovelo ${ }^{2}{ }^{(D}$, Ada Rebeca Contreras Rodríguez ${ }^{2}$ \\ and Sandra Dávila-Hernández ${ }^{1}$
}

check for updates

Citation: Ortiz Letechipia, J.; González-Trinidad, J.; Júnez-Ferreira, H.E.; Bautista-Capetillo, C.;

\section{Robles-Rovelo, C.O.; Contreras}

Rodríguez, A.R.; Dávila-Hernández,

$S$. Aqueous Arsenic Speciation with

Hydrogeochemical Modeling and

Correlation with Fluorine in

Groundwater in a Semiarid Region of

Mexico. Water 2022, 14, 519. https://

doi.org/10.3390/w14040519

Academic Editor: Dimitrios

E. Alexakis

Received: 10 December 2021

Accepted: 6 February 2022

Published: 9 February 2022

Publisher's Note: MDPI stays neutral with regard to jurisdictional claims in published maps and institutional affiliations.

Copyright: (C) 2022 by the authors. Licensee MDPI, Basel, Switzerland. This article is an open access article distributed under the terms and conditions of the Creative Commons Attribution (CC BY) license (https:// creativecommons.org/licenses/by/ $4.0 /)$.
1 Doctorado en Ciencias de la Ingeniería, Universidad Autónoma de Zacatecas, Campus UAZ Siglo XXI, Carretera Zacatecas-Guadalajara Km. 6, Ejido La Escondida C.P. 98160, Mexico; jenniol@uaz.edu.mx (J.O.L.); baucap@uaz.edu.mx (C.B.-C.); sadahe7@gmail.com (S.D.-H.)

2 Licenciatura en Ciencias y Tecnología del Agua, Campus UAZ Siglo XXI, Carretera Zacatecas-Guadalajara Km. 6, Ejido La Escondida C.P. 98160, Mexico; octavio.robles@uaz.edu.mx (C.O.R.-R.); rebeca.contreras@uaz.edu.mx (A.R.C.R.)

* Correspondence: jgonza@uaz.edu.mx (J.G.-T.); hejunez@uaz.edu.mx (H.E.J.-F.)

\begin{abstract}
In arid and semiarid regions, groundwater becomes the main source to meet the drinking water needs of large cities, food production, and industrial activities. For this reason, necessary studies must be carried out to estimate its quantity and quality, always seeking sustainable management, thus avoiding social conflicts or a decrease in the productive activities of humanity. This research explains the behavior of groundwater quality concerning arsenic speciation and its relationship with fluoride. The average total arsenic concentration of $19.95 \mu \mathrm{g} / \mathrm{L}$ and $20.29 \mu \mathrm{g} / \mathrm{L}$ is reported for the study period from 2015 to 2020, respectively, according to the Mexican standard. If the population drinks water directly, it is exposed to possible damage to health. The predominant arsenic species is As (V), with 95\% and As (III) with 5\%, this finding will allow us to define in greater detail the type of remediation that is required to reduce the content of this element in the water. Regarding the relationship between arsenic and fluorine, very small Pearson correlation coefficients of the order of 0.3241 and 0.3186 were found. The estimation of the space-time variation made it possible to identify the areas with the highest concentration of arsenic and fluorine, allowing the definition of the operating policies of these wells, thereby protecting the health of the inhabitants who consume this water.
\end{abstract}

Keywords: arsenic speciation; fluor; groundwater; hydrogeochemical modeling

\section{Introduction}

Groundwater is an emerging source that Mexicans have to meet their water needs for different activities. However, arsenic concentrations in groundwater have been reported for years in semiarid regions of Mexico, higher than the values suggested in the standard. Some studies have shown co-occurrence with fluorine [1-7]. Approximately 6 million Mexicans are exposed to high concentrations of arsenic and fluorine, especially in central-northern arid region where predominant geology is characterized by outcrops of Paleozoic and Mesozoic sedimentary rocks, Tertiary igneous rocks, and marsh and lake deposits. Mine tailings and mineral deposits of hydrothermal origin can be a contributing factor to the presence of As in soils, sediments, and groundwater [5,6,8-10]. This is a problem with worldwide relevance, where high concentrations of this element in groundwater have been reported in different places throughout history; some relevant reports are observed in Table 1. The arsenic footprint occurs throughout the world in different ways (rocks, sediments, soil, water). However, most of this geogenic contamination is deposited in 
alluvial aquifers, exposing 94 million people [11]. The main continent affected by this problem concerning its population is Asia, followed by Africa and South America [10-13].

The World Health Organization (WHO) has established an arsenic concentration limit in groundwater of $10 \mu \mathrm{g} / \mathrm{L}$ due to its carcinogenic and toxic effects on human health [14], while Mexican norms establish $25 \mu \mathrm{g} / \mathrm{L}$ [15].

Table 1. Reported occurrences of high arsenic concentration in groundwater worldwide.

\begin{tabular}{ccc}
\hline Country & As $(\mu \mathrm{g} / \mathrm{L})$ & Reference \\
\hline Afghanistan & $100 *$ & {$[16]$} \\
Africa & $1760 *$ & {$[17,18]$} \\
Argentina & $3810^{*}$ & {$[7,19]$} \\
Bangladesh & $>1000$ & {$[12,20-22]$} \\
Chile & $770 *$ & {$[7,19]$} \\
China & $850 *$ & {$[23]$} \\
Cyprus & $64 *$ & {$[24]$} \\
Finland & $980 *$ & {$[25]$} \\
Greece & $>1000$ & {$[24]$} \\
Hungary & $68 *$ & {$[26]$} \\
India & $50 *$ & {$[27,28]$} \\
Mexico & $241 *$ & {$[29,30]$} \\
USA & $210 *$ & {$[31,32]$} \\
\hline
\end{tabular}

* Maximum values.

Composition of water is the result of complex interactions between physical and chemical processes that take place along the flow, mainly from chemical interaction with minerals, gases, and organic matter and the mixture with other waters due to dispersion and diffusion [1,33-35]. In general, composition of groundwater can be traced along a flow line, from the sampling point to the recharge zone [36]. Compositional changes in an aqueous solution as a result of its flow in a porous subterranean medium were recognized and highlighted by Chebotarev (1955) [37], who in his extensive contribution determined the evolutionary sequence of groundwater.

Several investigations have been carried out to understand the mechanism of evolution of ions in groundwater $[7,8,29,33,38]$ and, based on this, to determine its trajectory and the geological environment through which it has passed. This allows identifying elements that can generate health issues using water in different activities. However, there are still many questions, especially for those that produce severe human health problems, such as arsenic in water. Therefore, this research is focused on contributing to understanding the (spatiotemporal) behavior of arsenic through monitoring the evolution and type of arsenic found in water used for drinking or irrigation purposes. Humans can ingest arsenic through direct drinking of water or food consumption; it has been reported that arsenic is extremely carcinogenic, and it also has negative chronic effects through long-term ingestion in low concentrations.

In this area of study, an investigation such as this has not been carried out; there have only been reports published over time stating that the problem of high concentrations of arsenic is becoming worse. Neither remediation technologies have been implemented to control this problem, which is why this study is relevant for the region, as well as for its inhabitants, to choose or create an adequate and effective remediation method for this type of problem.

Studies suggest the presence of As in hundreds of compounds, including mineral forms; for this reason, it is important to study the speciation in groundwater. Geochemical composition of an aquifer has direct control over groundwater quality due to the release of arsenic, aggravated by other anthropogenic activities [8,18,38-42].

Toxicity depends on oxidation state, chemical structure, and solubility. Arsenic toxicity scale diminishes in the subsequent direction: Arsines $>\mathrm{As}^{+3}$ inorganic $>\mathrm{As}^{+3}$ organic $>\mathrm{As}^{+5}$ inorganic $>\mathrm{As}^{+5}$ organic $>$ arsenical compounds and elemental arsenic [43]. In water, the pres- 
ence is due to the natural mineral's dissolution from geological deposits, discharge of effluents, and atmospheric sedimentation. In surface water with high oxygen content, the most common component is the pentavalent or arsenate $\left(\mathrm{As}^{+5}\right)$. Under reduction conditions, generally in groundwater or lake sediments, trivalent arsenic or arsenite predominates $\left(\mathrm{As}^{+3}\right)$ [1,44-46].

Monitoring water quality for human consumption and different activities must be performed permanently in short time intervals, to detect the presence or evolution of any element that is outside the norm established by the specific country or organization such as the World Health Organization (WHO). In this research, it is proposed that early identification of arsenic-affected areas can serve as a milestone in creating remediation programs and in providing safe drinking water for the population. Therefore, one of the scientific challenges is to explain the As (III)/ As (V) ratio, related to the variation in redox conditions, microbiological activity, water sources, and environmental conditions. These processes are regulated by redox potential, $\mathrm{pH}$, chemical composition of the system, competing anions, minerals in the aquifer, and reaction kinetics [27,47-50]. In addition, there is evidence that arsenic in groundwater is associated with the presence of fluoride, for which it is of scientific interest to determine its possible relationship. This will allow defining better water quality, thus avoiding harmful effects on public health. This work contributes to the SDGs, clean water and sanitation, good health and wellbeing, industry, innovation and infrastructure, and sustainable cities and communities [51].

The aims of this work were (1) to determine the space-time evolution of arsenic and its speciation in groundwater of an alluvial aquifer through hydrogeochemical modeling, and (2) to relate the concentration of arsenic to fluorine using the Verma model in a semiarid region of Mexico with hydrogeochemical modeling through 5-year difference samples.

\section{Materials and Methods}

\subsection{Description of the Study Area}

The study area comprises the administrative aquifers of Calera, Chupaderos, and Benito Juarez, Mexico (Figure 1). It is located at the central portion of Zacatecas; between parallels $22^{\circ} 47^{\prime}$ and $23^{\circ} 42^{\prime}$ of north latitude and between the meridians $102^{\circ} 39^{\prime}$ and $103^{\circ} 01^{\prime}$ of west longitude, covering an approximate area of $5060 \mathrm{~km}^{2}$ (Figure 1) [52].

\subsection{Geological Features}

Zacatecas comprises four geological provinces: Sierra Madre Occidental, Sierra Madre Oriental, Mesa del Centro, and Eje Neovolcánico. Rocks are of all the fundamental types, igneous, sedimentary, and metamorphic, whose formation ages correspond from the Triassic to the Recent. The oldest are low-grade metamorphic rocks (phyllites, shales, and schists). Cenozoic igneous rocks appear with their characteristic structures (volcanic devices and lava flows) and in intrusive bodies that affect pre-existing rocks (Figure 1) [53].

In the study region, alluvium predominates, also called fill material, where most of the wells are located; followed by igneous rocks. The main types of soils are kastanozem (the average is characterized by having a depth of two meters where clay predominates); regosol has a coarse granulometry; gypsisol has a medium texture with a low moisture retention capacity and a slope of $8 \%$; finally, the feozem with high clay content and black color (Figure 2) [54].

\subsection{Sample Collection and Concentration Determination}

A campaign was carried out with 182 groundwater samples from each year (2015 and 2020). The ideal would be to monitor all existing wells, to identify in greater detail the mobility of arsenic constantly, however, this requires economic resources, and sometimes in underdeveloped countries, it is not possible to access this. For this reason, monitoring networks are created that allow knowing the state of the region. Infield, electrical conductivity (EC), total dissolved solids (TDS), hydrogen potential ( $\mathrm{pH})$, and dissolved oxygen were measured. An isolation cell was used to prevent atmospheric interaction and achieve stability. Alkalinity test was performed, with a brand titration device $\mathrm{HACH}(\mathrm{Hach}$ Company, 
Loveland, $\mathrm{CO}, \mathrm{USA}$ ) which includes cartridges containing $\mathrm{H}_{2} \mathrm{SO}_{4}$ at 0.16 normal concentration (N). Concentrations of $\mathrm{CO}_{2}{ }^{2-}$ and $\mathrm{HCO}_{3}{ }^{-}$ions were obtained through equilibrium point determination with phenolphthalein and bromophenol blue indicators. All samples were collected in plastic bottles and filtered $(0.45 \mu \mathrm{m})$, ensuring elimination of dissolved solids that could affect subsequent determinations. Samples were transported and stored at a temperature of $4{ }^{\circ} \mathrm{C}$.

Analytical determinations were performed in the Hydrogeochemistry Laboratory of Autonomous University of Zacatecas, and samples were analyzed by atomic absorption spectrophotometry (Thermo Scientific ICE AA 3300, Waltham, MA, USA) with generation of hydrides. Determinations of major ions $\mathrm{Ca}^{2+}, \mathrm{Na}^{+}, \mathrm{K}^{+}$, and $\mathrm{Mg}^{2+}$ were evaluated using the same equipment. Chloride was determined by titration using $\mathrm{AgNO}_{3}$ and $\mathrm{K}_{2} \mathrm{CrO}_{4}$ indicators. Other anions were determined by colorimetry; $\mathrm{SO}_{4}{ }^{2-}$ by precipitation of $\mathrm{BaSO}_{4} ; \mathrm{N}-\mathrm{NO}_{3}$ by the automated cadmium reduction method. Calibrations for atomic absorption spectrophotometry and automated colorimetry were made using an appropriate dilution standard. Additional control includes ion balance - below $\pm 7 \%$. The precision of physicochemical parameters was verified using ionic equilibrium error (EBI), and cations and anions are expressed in meq/L (Equation (1)) with a permissible limit of $\pm 10 \%$.

$$
\mathrm{EBI}=\Sigma \text { anions }-\Sigma \text { cations } / \Sigma \text { cations }+\Sigma \text { anions } * 100 \text {. }
$$

All determinations were made under the guidelines described in APHA-SMWW 2006 [55] and applicable Mexican regulations.

\subsection{Analysis of Data}

\subsubsection{Mapping of Parameters}

Concentrations of arsenic and fluorine were analyzed with ordinary Kriging (ArcMap 10.1, Esri's ArcGIS, Redlands, California, USA). This geostatistical method estimates surface from a set of scattered points with z-values. It uses a math function to some points within a specified radius and determines the output value for each location. Kriging is a multistep process: exploratory statistical analysis of data, variogram modeling, surface creation, and variance surface exploration.

The general formula is (Equation (2)):

$$
\hat{Z}\left(S_{0}\right)=\sum_{i=1}^{N} \lambda_{i} Z\left(S_{i}\right),
$$

where $Z\left(S_{i}\right)$ is the measured value at the location, $\lambda_{i}$ is an unknown weight for the value measured, $S_{0}$ is the location of the prediction, and $N$ is number of measured values $[56,57]$.

\subsubsection{Hydrogeochemical Modeling}

Hydrogeochemical modeling for speciation of arsenic was carried out with PHREEQC version 3.0 (PHREEQC, USGS Water Resources Mission Area, Reston, VA, USA) software based on the database WATEQ4F.dat. The program implemented the ion-associated theory of aqueous solutions and Debye-Hückel expressions to execute various aqueous geochemical calculations [58,59].

According to the Debye-Hückel theory, single-ion activity coefficient $\Upsilon_{i}$ of ion $i$ in a solution of one or more electrolytes is given by (Equation (3)):

$$
\ln \curlyvee i=\frac{A_{D H} z_{i}^{2} \sqrt{I m}}{1+B_{D H} a \sqrt{I m}}
$$

where $z_{i}$ is the charge number of ion $i$; Im the ionic strength of solution on a molality basis; $A_{D H}$ and $B_{D H}$ are defined functions of the kind of solvent; and $a$ is an adjustable parameter, equal to the mean effective distance of closest approach of other ions in the solution to one of the $i$ ions [60]. 
PHREEQC rewrites all chemical equations in terms of master species. One master aqueous species is associated with each element, or valence state, the activity of hydrogen ion, of the aqueous electron, and water. This reduces the number of unknowns to minimum and iteratively refines values until a solution to the set of algebraic equations is found. Master unknowns for aqueous solutions are the natural log of the activities of master species, activity of water, ionic strength, and mass of solvent water in an aqueous solution [58,61-63].

\subsubsection{Statistical Analysis}

For statistical analysis of the relationship between arsenic species and fluorine, we carried out a linear regression model of least-squares weighted by uncertainty (UWLR) in Bivariate Data Analysis System software (RMIQ_2018: BiDASys, UNAM, CDMX, Mexico). This is a novel weighted linear regression method founded on estimations of total uncertainty with a strict confidence level of $99 \%$. The software uses studentized residuals for linear regression models using Equation (4):

$$
S r_{j}=\left|\frac{r_{j}}{\sqrt{\frac{\sum r_{j}^{2}}{n-2}} \sqrt{\left(1-\frac{1}{n}\right)-\left(\frac{\left(x_{j}-\bar{x}\right)^{2}}{\sum\left(x_{j}-\bar{x}\right)^{2}}\right)}}\right|
$$

where $S r_{j}$ represents the studentized residuals; $r_{j}$ the residuals calculated by each linear regression; $n$ the number of samples; and $x_{j}$ and $\bar{x}$ the individual value and the mean from sample $x$, respectively [54].

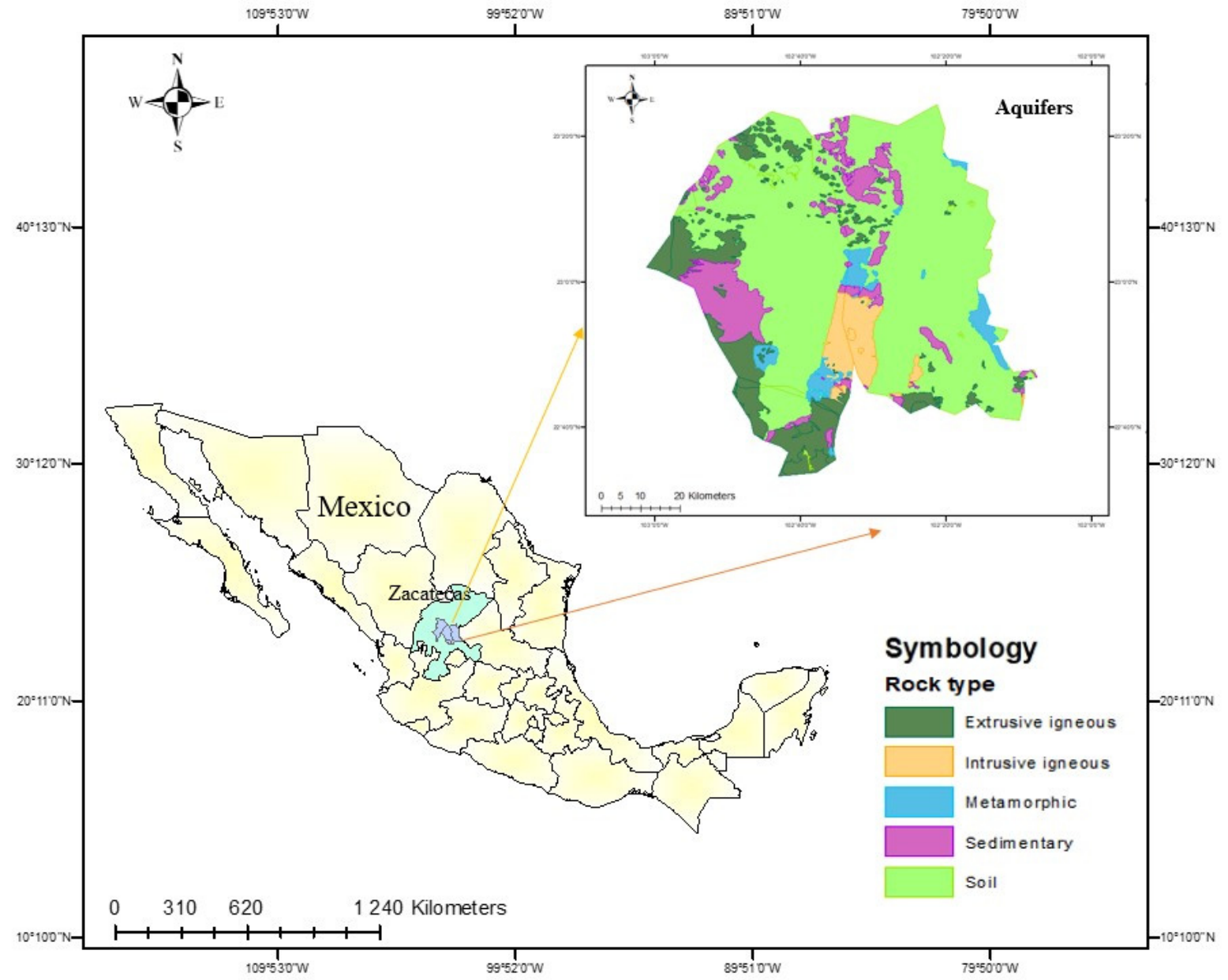

Figure 1. Study area: State of Zacatecas, Mexico, and the corresponding geology of the aquifers. 


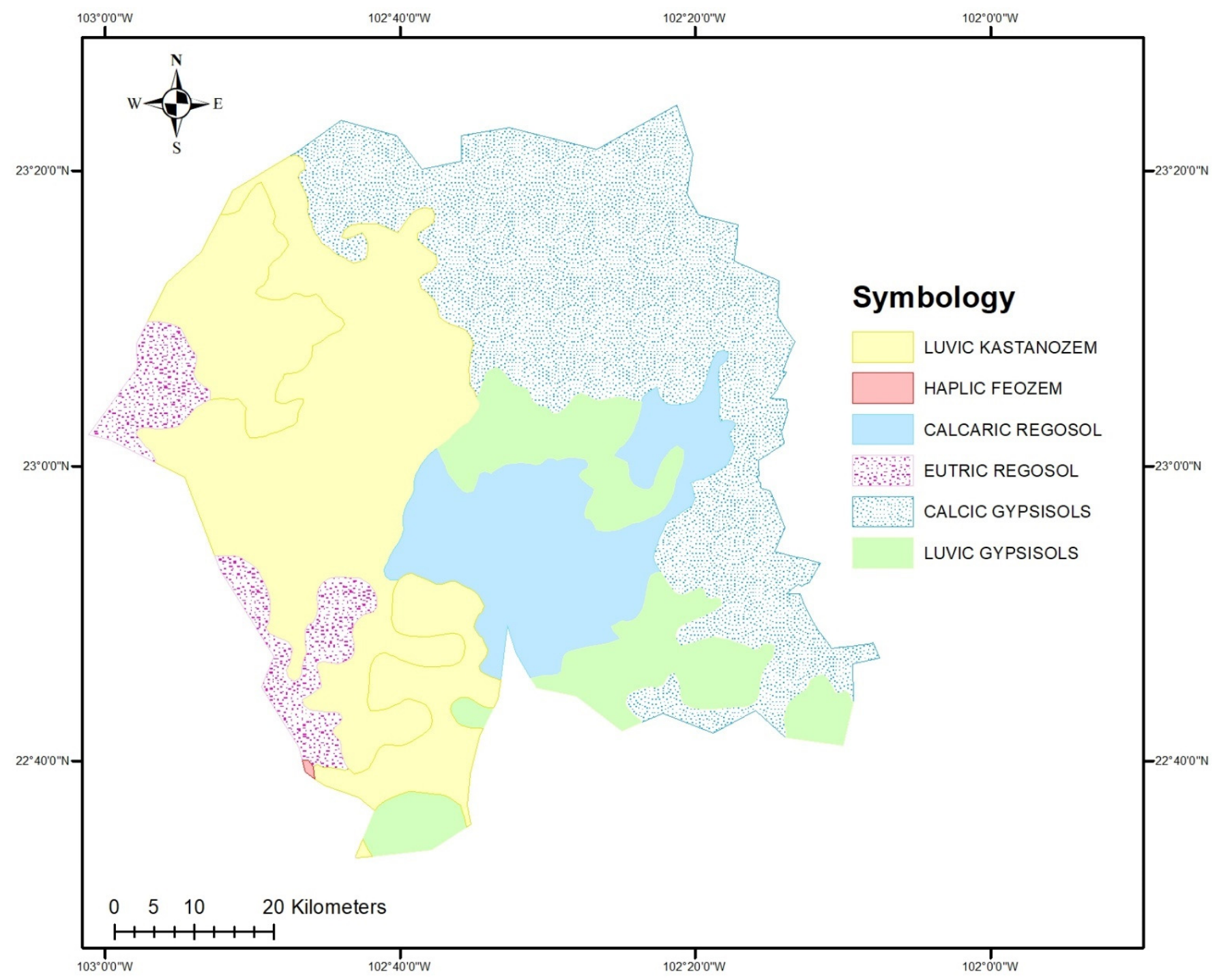

Figure 2. Edaphology of the study area.

\section{Results and Discussion}

Long-term geogenic exposure to arsenic in water is a public health concern. This problem is aggravated in semiarid regions such as the one studied in this research. The species of inorganic forms (generally the most toxic to the human body) of arsenic are relevant to understand because of its interaction with biota, mobilization, adsorption, and transport of elements in aquatic systems. Researchers [17,38,63], agree with this approach.

Groundwater, considered worldwide as an important source for human consumption, food production, industrial processes, and recreation, requires a physical, chemical, biologi$\mathrm{cal}$, and radioactive characterization. This determines possible risks in the end-users of the products generated with it, as reported in various investigations [21,64,65].

In the last 5 years, some investigations have focused on determining, in detail, the type of arsenic that occurs in groundwater, recommending investigating it by region, due to the particularity of each one of them. This research contributes to identifying the type of arsenic in groundwater from alluvium aquifers, thereby mitigating possible effects on final consumers.

It has also been reported that there exists, generally, a relationship between arsenic and fluorine, that is, when one is present, the other appears $[5,66,67]$. Therefore, it is necessary to identify this, through the application of models that relate variables, to understand this behavior. 
Results of the arsenic speciation analysis in the study region are presented below, where predominately groundwater is consumed and comes from these aquifers, as well as the relationship of As with fluorine obtained with the linear regression model of Verma, least-squares weighted by uncertainty (UWLR).

\subsection{Mapping of Arsenic}

Concentration of total arsenic in the monitoring wells of Chupaderos and Benito Juárez aquifer ranged from 4-27 $\mu \mathrm{g} / \mathrm{L}$ (Figure 3); these values are within the limit established by Mexican regulation $(25 \mu \mathrm{g} / \mathrm{L})$. Therefore, this area is safe for its agricultural, industrial, urban public, and recreational use. Similar results have been reported in investigations, with the difference that some of the aquifers are of the karstic type $[43,68,69]$.

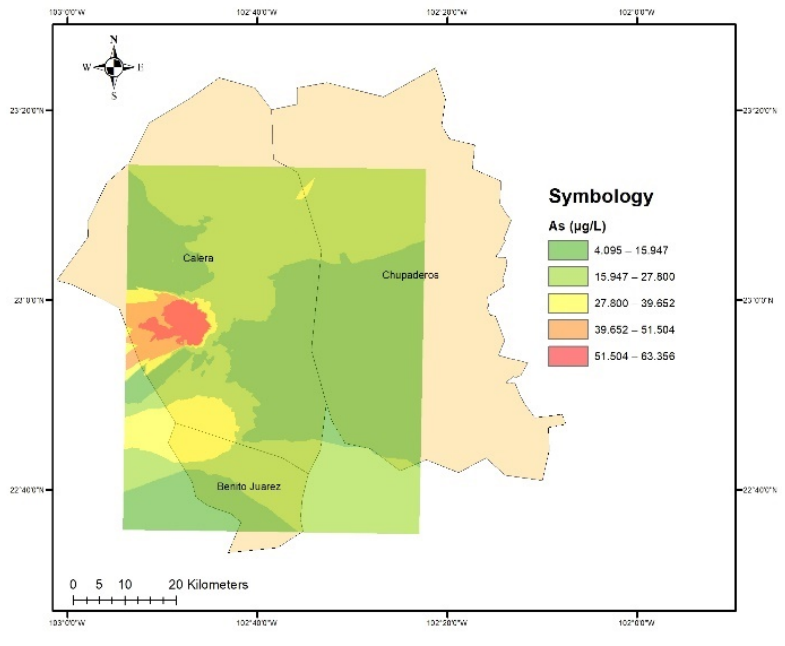

(a)

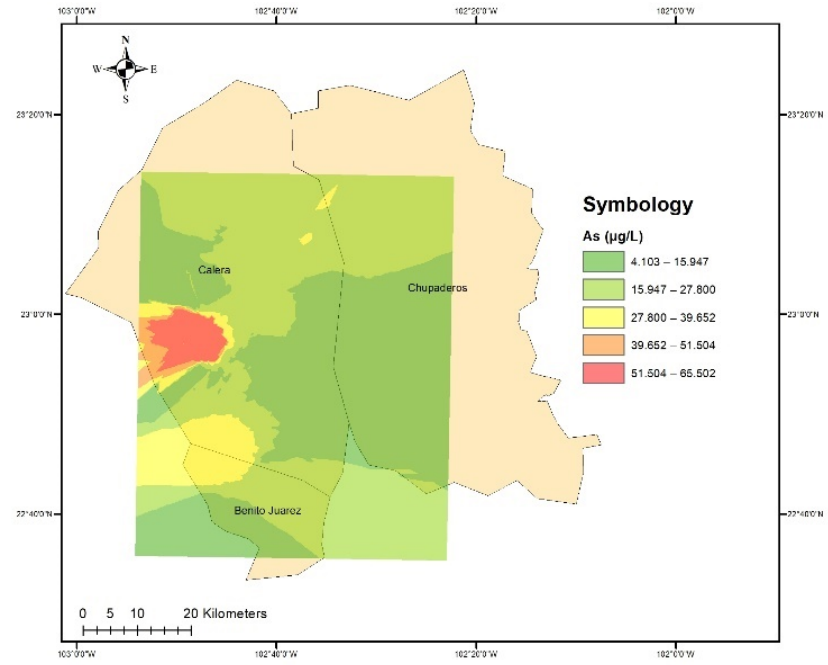

(b)

Figure 3. Total arsenic concentration in groundwater of the study area: (a) 2015; (b) 2020.

However, the southwest of the Calera aquifer shows a region to the west with a zone of very high concentrations, with values between 39-66 $\mu \mathrm{g} / \mathrm{L}$, exceeding the WHO and Mexican standards. This contamination is of a natural type since the aquifers are located on a region of sedimentary rocks (pyrite) as seen in Figure 1; in the same way, areas that begin to increase their content of this element are part of igneous rocks within the region, which indicates a relationship established in the literature that this element is associated with this type of geology $[18,41,43,70,71]$. These data rule out anthropogenic contamination for this area.

This comportment is parallel for both years, with the difference that the red zone worsens for 2020 (Figure 3). Water in this region is not suitable for any of the activities mentioned above. Ortiz-Letechipia et al. [29], reaffirms this, according to the water quality index.

Considering the concept of total arsenic and the spatial and temporal distribution observed in this work, very few investigations report this $[30,64]$. It was found that the most abundant species in this area is the pentavalent (Figure 4).

Assuming that water is consumed directly and indirectly through food, a less aggressive effect on human health would be expected, since As III is more toxic. However, it can sometimes be metabolized in the liver to become its trivalent species [19,22,41,65-68]. The distribution of concentration of As $(\mathrm{V})$ presents a red zone that exceeds the limits at the west of Calera aquifer. Therefore, it is important to constantly monitor and analyze the behavior of this element in groundwater. 


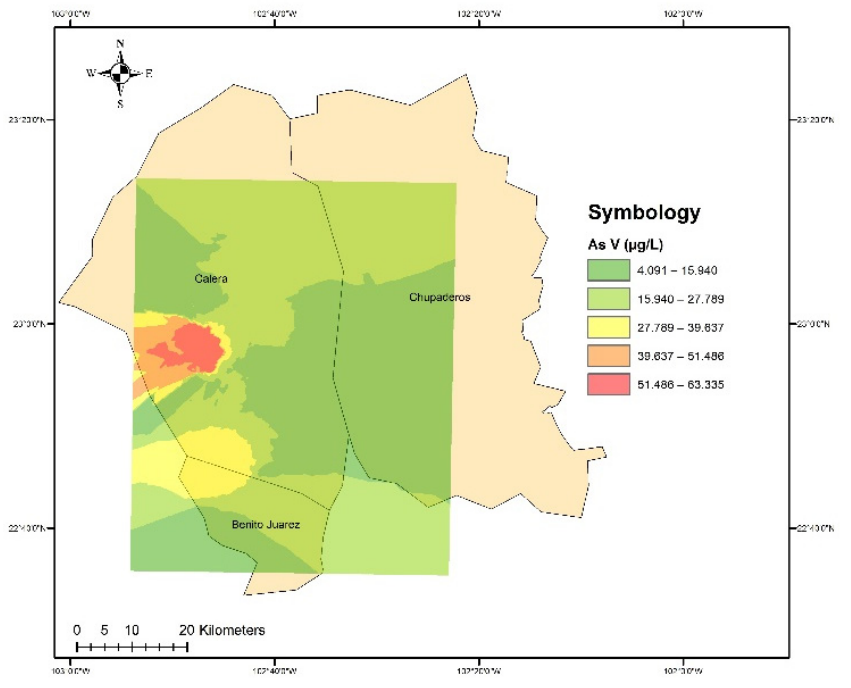

(a)

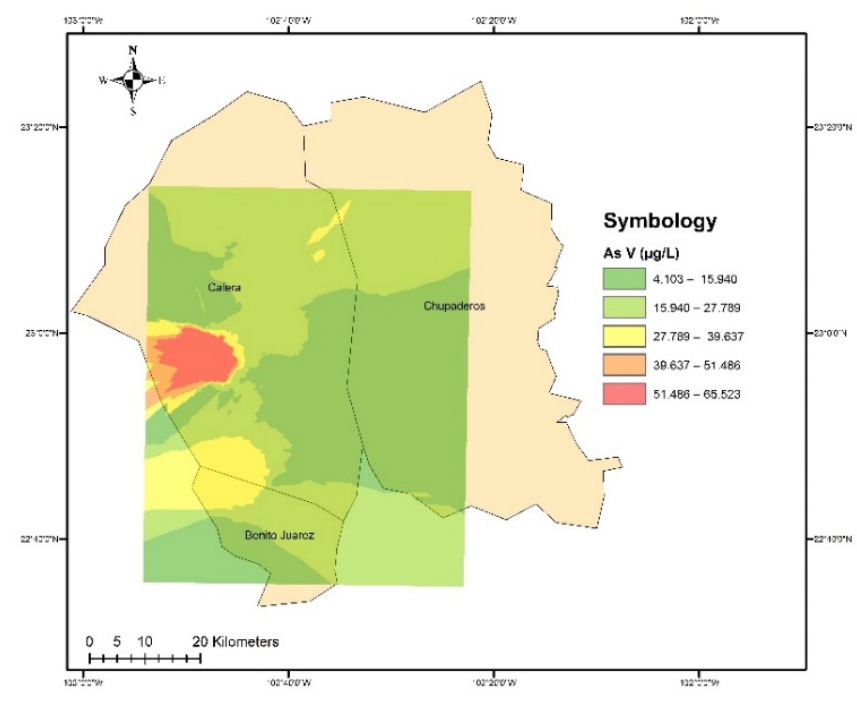

(b)

Figure 4. As (V) concentration in groundwater of the study area: (a) 2015; (b) 2020.

For species of As (III), hydrogeochemical modeling shows very low concentrations. It can be observed that in the northern part, the presence of this is slightly higher than the rest of the zone. It is also observed that in 2020 the amount of As (III) decreased compared to 2015, which may indicate that As (V) increased in five years (Figure 5).

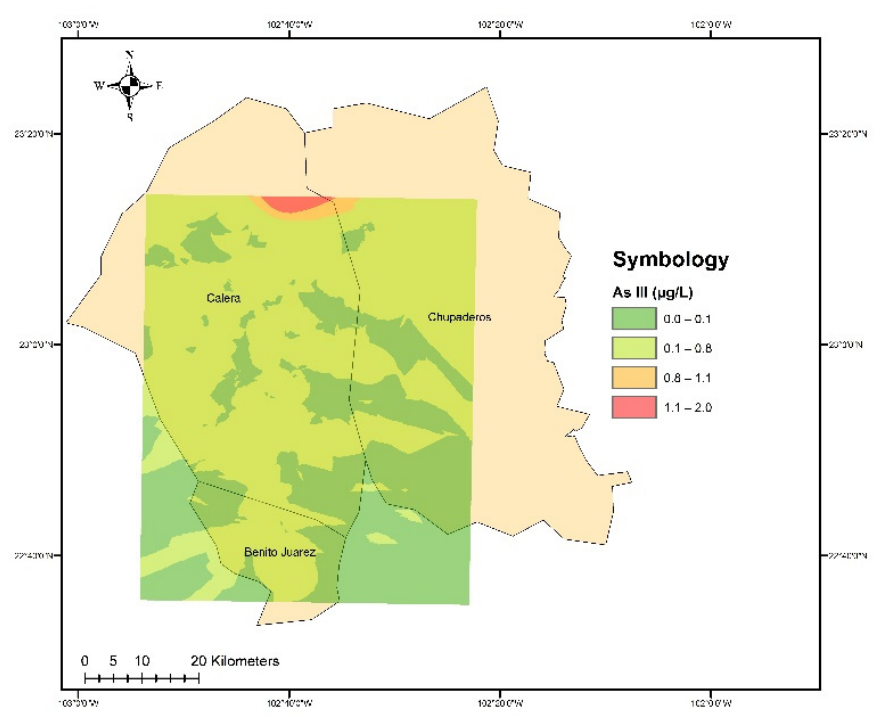

(a)

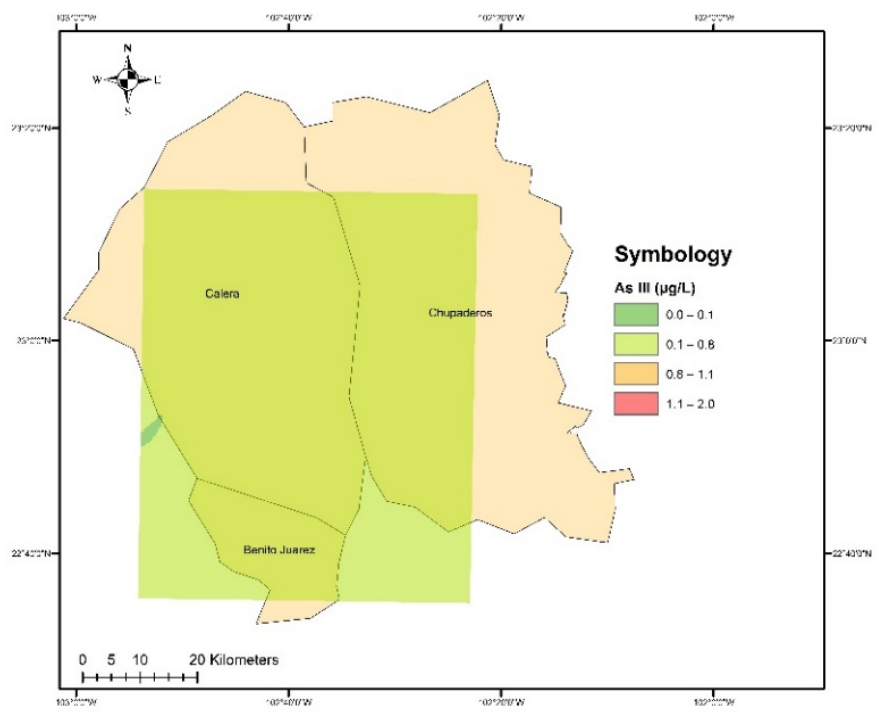

(b)

Figure 5. As (III) concentration in groundwater of the study area: (a) 2015; (b) 2020.

It is extremely important to study speciation of arsenic in groundwater to apply the best possible remediation method. All existing methods have advantages and disadvantages; some of them only remove pentavalent species or trivalent species, so sometimes it is necessary to use some oxidizing or reducing substance that increases its cost. Choosing the appropriate method requires prior analysis and recurrent monitoring of the area in order to carry out successful remediation [28,69-72]. It is also relevant to know the speciation of arsenic because groundwater is also used for other activities such as irrigation in agriculture, where arsenic can reach plants and food, and we consume increasing risk of exposure. 
The challenge of having identified the arsenic speciation present in the groundwater allowed planning the ideal type of remediation for this area. The use of a biosorbent material is being considered and is still under investigation. This is to improve the quality of the water, thereby helping the drinking water operator to deliver it, with arsenic content below the Mexican standard.

In the space-time comparison of arsenic speciation, it is found that in 2015 , an As III plume was identified in the north of the study area; however, by 2020, it disappeared (Figures 4 and 5). This is probably due to evolution from As III to As V due to the mixture of flows resulting from the extraction of water $[8,29,73]$. This change can also be attributed to mobilization/retention processes, dissolution, bacteria-mediated electrochemical evolution, geology, and ion exchange $[33,46,74,75]$. The occurrence of this phenomenon favors remediation methods that have an affinity for As V $[45,76]$.

\subsection{Hydrogeochemical Modeling}

Hydrogeochemical modeling shows that the species of As (V) is the one that occurs mostly for the analyzed samples, while that of As (III) is found in very small quantities in both years (Figure 5). In 2015, average total As concentration was $19.95 \mu \mathrm{g} / \mathrm{L}$, As (V) $19.92 \mu \mathrm{g} / \mathrm{L}$, and As (III) $0.0271 \mu \mathrm{g} / \mathrm{L}$. In 2020, average total As concentration was $20.29 \mu \mathrm{g} / \mathrm{L}$, As (V) $20.28 \mu \mathrm{g} / \mathrm{L}$, and As (III) $0.0108 \mu \mathrm{g} / \mathrm{L}$ (Figure 6). A space-time increase of $0.34 \mu \mathrm{g} / \mathrm{L}$ in total arsenic was observed in 2020; this may be because water is being extracted at greater depths.

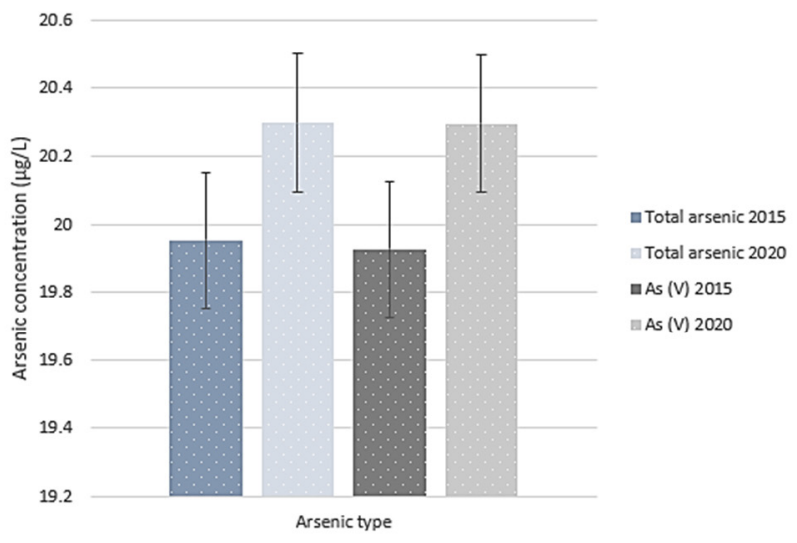

(a)

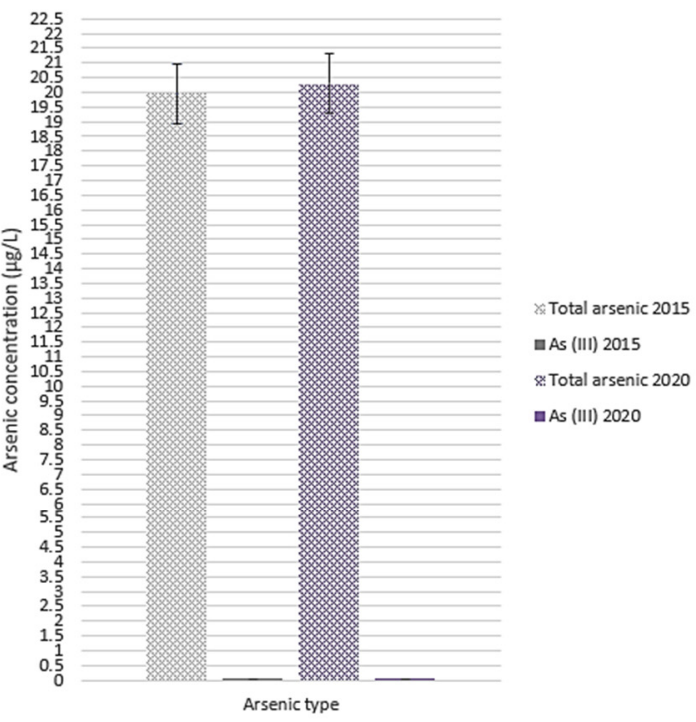

(b)

Figure 6. Comparison of total arsenic in groundwater of the study area with (a) As (V) and (b) As (III).

This outcome is similar to other research located in the central-northern part of Mexico, in the Rio Verde basin, Mexico [46], but it differs from the research carried out in Rayong province, eastern Thailand Satika in coastal alluvial aquifers where As (III) was the most abundant species [1]. This research shows that the mapping and speciation of the type of arsenic is important, as even if you have the same type of aquifer, the arsenic found may be different. This occurs due to various factors such as climate, precipitation, mobilization, groundwater extraction, and other anthropogenic activities. In addition, the specific application of the type of remediation is important, not only as an already established theoretical concept [11,49]. 


\subsection{Statistical Analysis}

Associated with the presence of high elevated As, concentrations of fluorine have been found. Calera and Benito Juárez aquifers present this behavior in the northwest and south with values of 1.49-1.75 mg/L above the Mexican and WHO standards for water for human consumption, while the Chupaderos aquifer presented low concentrations $(0.46-0.98 \mathrm{mg} / \mathrm{L})$, complying with the Mexican standard. For 2020, it is observed that the high concentrations of fluoride increased in the northwest for 2015, and similar results were shown for arsenic (Figure 7). This demonstrates the contribution of this research, that with a space-time analysis of the elements, the application of specific remediations is improved, thereby achieving significant savings of money and human resources for decision-makers on the use of groundwater. There are only a few studies that analyze this behavior, as well as the toxicity of fluoride with arsenic, two elements that have potentially harmful effects on public health $[29,77]$.

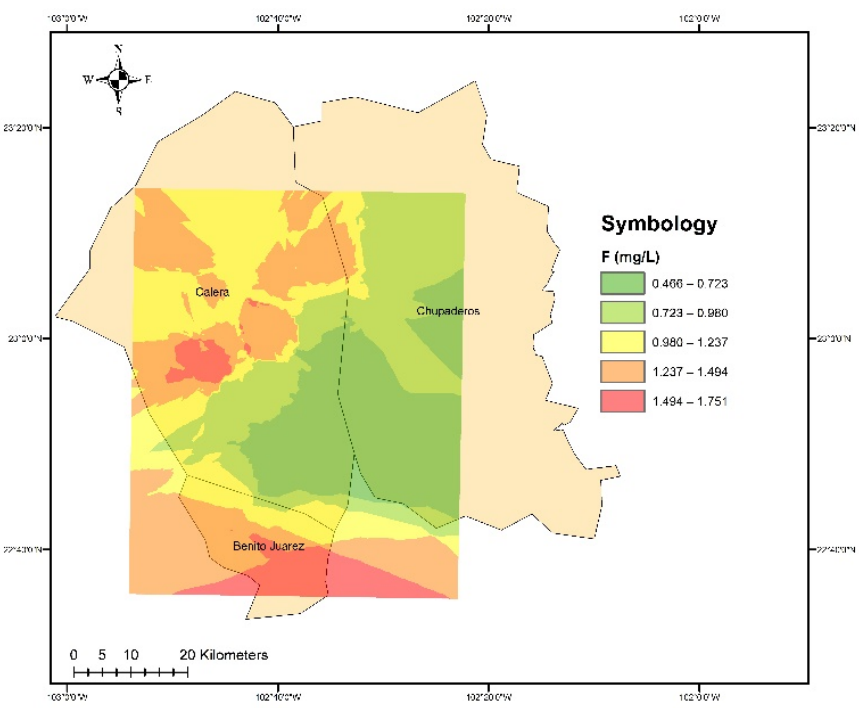

(a)

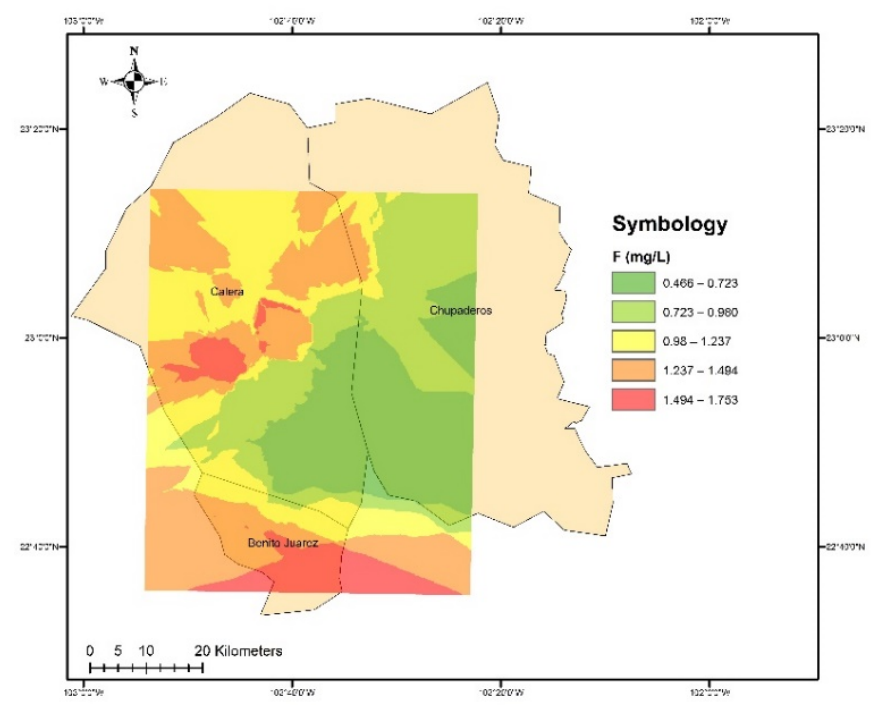

(b)

Figure 7. Fluorine concentration in groundwater of the study area: (a) 2015; (b) 2020.

Some investigations have shown the relationship between arsenic and fluorine, using techniques such as linear regression, main components, or the regression coefficient [78]. With total arsenic, an innovative model called BiDASys was used to demonstrate this possible correlation, which allows a more detailed analysis of the relationships between variables. A contribution of this research is that it performs the correlation between the speciation of the arsenic found and the fluorine through the BiDASys model (Figure 8), applied in very few investigations.

It is observed that the derivative is very similar for the two periods studied, reporting an increase of seven units of fluorine per unit increase of arsenic in the water. However, if we consider the Pearson correlation coefficient, which was 0.3241 for 2015 and 0.3186 for 2020 , there is a very low relationship as this coefficient should be between 1 and 0.7 for a good correlation [79].

This correlation indicates that, as in other previously reported studies [5,80-83] regarding the co-occurrence of arsenic with fluorine, it is relevant to understand the contamination of both elements as well as to predict the possible health effects that these elements cause with drinking water. These results are similar to the reported by Navarro et al. in 2017 [38]. 


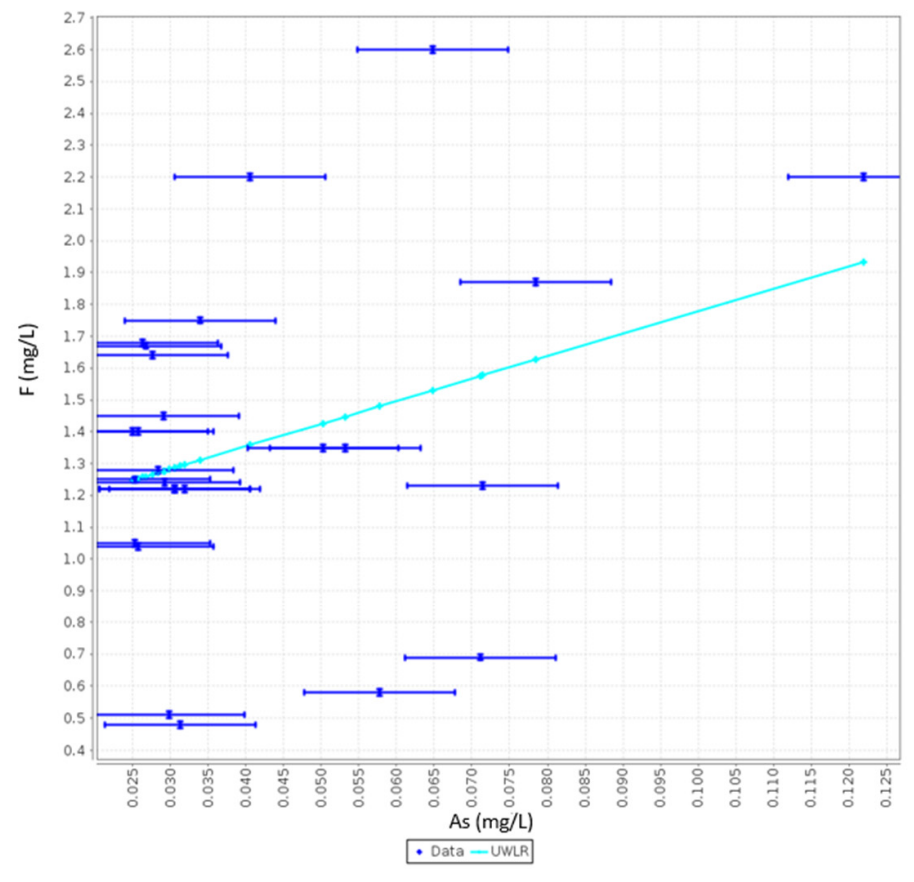

(a)

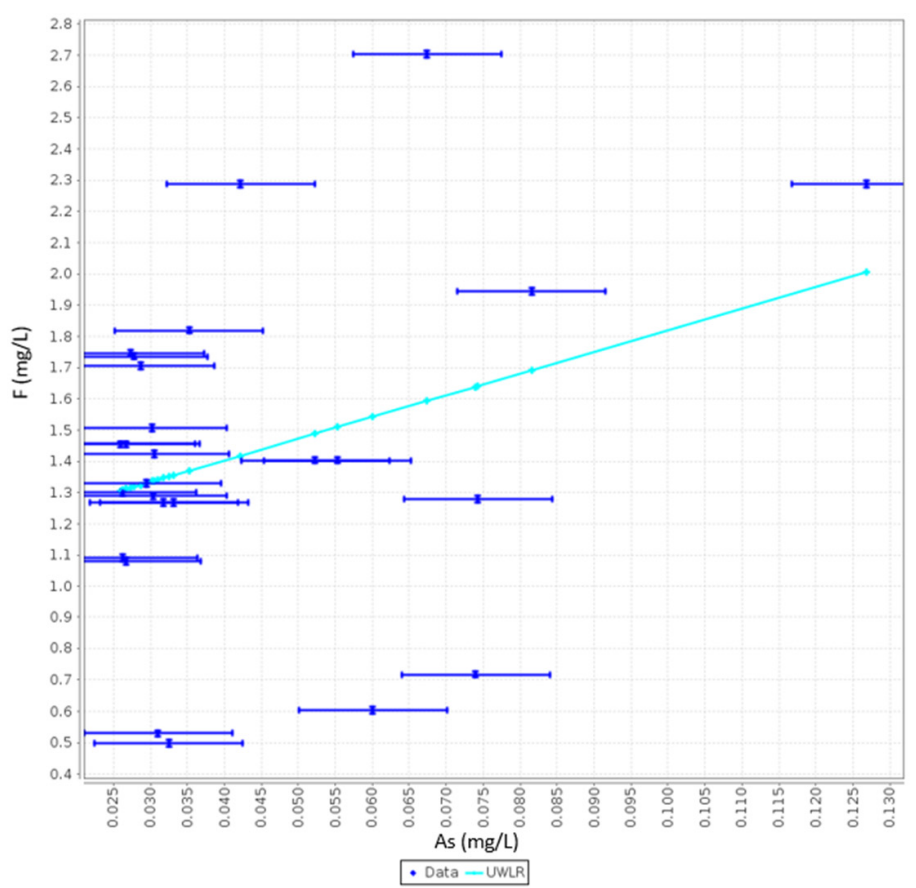

(b)

Figure 8. As and F correlation for the highest values of As: (a) 2015; (b) 2020.

The model found is shown in Equation (5) for 2015 and Equation (6) for 2020:

$$
\begin{aligned}
& y=7.072 x+1.071 \\
& y=6.933 x+1.126
\end{aligned}
$$

The origin of both elements comes from the dissolution of original rocks and contaminants retained in secondary minerals. Among them, iron oxides and clays, which, together with organic matter, have a large number of adsorption sites on their surface, strongly attracting arsenic and fluorine $[77,84]$. The processes mentioned above are also accelerated by the exploitation of aquifers as well as geothermal and mining activities [5].

\subsection{Applications of This Work}

Arsenic speciation allows us to know the behavior and mobilization of this element in groundwater for different purposes, for example, to find an adequate remediation method that helps to improve the quality of life of the population, providing safe drinking water. In addition, it helps us to identify critical zones that contain high limits of this element, to observe which are the safest aquifers that provide good quality water and avoid the extraction of those that can pose a risk to public health, and to control this problem in the design of wells, by tracing the stratum where the arsenic is located and placing a blind tube instead of grooved.

Determining that the most frequent arsenic species in water was As (V) type (a species less toxic to the organism than the trivalent one) provides relevant information to apply the best available remediation method, or to develop one that best suits it. Carrying out a study such as this allows proper planning of a remediation program. This contributes to saving economic resources, as well as time lost when implementing a remediation method that is not suitable for the study area. It also enables to know the critical areas where it is necessary to implement the appropriate technologies for the elimination of contaminants. For the industry (mainly agricultural that prevails in this area), it is very helpful to know the quality of the water that is extracted and the possible ways to improve it, as it influences the growth of the crops and the quality of the product that is produced. We are always 
looking for clean foods safe for humans. For this species, it has been reported that either organic or inorganic adsorbents are efficient in reducing high concentrations of arsenic, in addition to being low in cost and safe to improve groundwater quality.

This study also demonstrates that the use of the concept of administrative aquifers in Mexico must change: the entire study region must be taken into account because the established limits are subjective. The analysis of the mobility of arsenic allows us to observe this phenomenon in which this element changes over time due to various factors (climate, soil, anthropogenic activities, chemical balance, microorganisms, plants, etc.). Analysis also allows us to estimate the state of the water quality of the alluvial aquifers which supply the metropolitan area of the state.

\section{Conclusions}

The behavior of total arsenic varied in a range from 0.10 to $250.95 \mu \mathrm{g} / \mathrm{L}$. From 2015 to 2020, an increase of $0.34 \mu \mathrm{g} / \mathrm{L}$ can be observed; this contamination has a geogenic origin. These data exceed the Mexican standard for domestic use. Most of the monitored wells are below this parameter; only one plume was identified in the southwest of the study region.

Arsenic speciation allows us to know the behavior and mobilization of this element in groundwater, to find an adequate remediation method that helps to improve the quality of life of the population, providing safe drinking water.

The predominant arsenic species found with hydrogeochemical modeling in the study area was As (V) in 2015 and 2020 (19.92 and $20.29 \mu \mathrm{g} / \mathrm{L}$ ), indicating oxidating conditions in the media.

In this investigation, using the linear regression model of least-squares weighted by uncertainty (UWLR) in Bivariate Data Analysis System software, the Pearson coefficients were determined to identify the ranges of the possible relationship. The values found were 0.3241 and 0.3186 for 2015 and 2020, respectively, indicating that high arsenic concentrations showed a low correlation with fluoride in both years. The co-occurrence of arsenic and fluorine is graphically observed in the study area, presenting high concentrations in similar regions.

Future research should be focused on the application and creation of safe, reliable, effective, sustainable, economical, and simple remediation methods. These procedures for the control of arsenic must be applied before water enters the network of conduction and distribution to houses of the inhabitants, in addition to continuous monitoring of the evolution of arsenic, to observe its behavior and mobilization, to carry out the necessary remediations and thereby avoid a harmful effect on the population.

Author Contributions: Conceptualization: J.O.L., J.G.-T., and A.R.C.R.; methodology, software, validation, and writing: J.O.L. and J.G.-T.; resources and supervision: H.E.J.-F., C.B.-C., and J.G.-T.; investigation: J.O.L.; writing—original draft: J.O.L.; writing—review and editing: J.O.L., J.G.-T., H.E.J.-F., C.B.-C., C.O.R.-R., A.R.C.R., and S.D.-H. All authors have read and agreed to the published version of the manuscript.

Funding: This research received no external funding.

Institutional Review Board Statement: Not applicable.

Informed Consent Statement: Not applicable.

Data Availability Statement: The data presented in this study are available in the article.

Acknowledgments: The authors express their gratitude to the Mexican National Council for Science and Technology (CONACYT) for financing the scholarship of the doctoral students. We deeply appreciate the recommendation and professional comments from the reviewers and the editor.

Conflicts of Interest: The authors declare no conflict of interest. 


\section{References}

1. Boonkaewwan, S.; Sonthiphand, P.; Chotpantarat, S. Mechanisms of arsenic contamination associated with hydrochemical characteristics in coastal alluvial aquifers using multivariate statistical technique and hydrogeochemical modeling: A case study in Rayong province, eastern Thailand. Environ. Geochem. Health 2021, 43, 537-566. [CrossRef] [PubMed]

2. Brown, R.M.; McClelland, N.I.; Deininger, R.A.; Tozer, R.G. A water quality index-Do we dare? Water Sew. Work. 1970, 117, 339-343.

3. Sadat-Noori, S.M.; Ebrahimi, K.; Liaghat, A.M. Groundwater quality assessment using the Water Quality Index and GIS in Saveh-Nobaran aquifer, Iran. Environ. Earth Sci. 2014, 71, 3827-3843. [CrossRef]

4. Ram, A.; Tiwari, S.K.; Pandey, H.K.; Chaurasia, A.K.; Singh, S.; Singh, Y.V. Groundwater quality assessment using water quality index (WQI) under GIS framework. Appl. Water Sci. 2021, 11, 46. [CrossRef]

5. Alarcón-Herrera, M.T.; Bundschuh, J.; Nath, B.; Nicolli, H.B.; Gutierrez, M.; Reyes-Gomez, V.M.; Nuñez, D.; Martín-Dominguez, I.R.; Sracek, O. Co-occurrence of arsenic and fluoride in groundwater of semi-arid regions in Latin America: Genesis, mobility and remediation. J. Hazard. Mater. 2013, 262, 960-969. [CrossRef] [PubMed]

6. Litter, M.I.; Armienta, M.A.; Villanueva Estrada, R.E.; Villaamil Lepori, E.C.; Olmos, V. Arsenic in Latin America: Part II BT-Arsenic in Drinking Water and Food; Srivastava, S., Ed.; Springer: Singapore, 2020; pp. 113-182. ISBN 978-981-13-8587-2.

7. Bundschuh, J.; Litter, M.I.; Parvez, F.; Román-Ross, G.; Nicolli, H.B.; Jean, J.S.; Liu, C.W.; López, D.; Armienta, M.A.; Guilherme, L.R.G.; et al. One century of arsenic exposure in Latin America: A review of history and occurrence from 14 countries. Sci. Total Environ. 2012, 429, 2-35. [CrossRef]

8. Dorjderem, B.; Torres-Martínez, J.A.; Mahlknecht, J. Intensive long-term pumping in the Principal-Lagunera Region aquifer (Mexico) causing heavy impact on groundwater quality. Energy Rep. 2020, 6, 862-867. [CrossRef]

9. Camacho, L.M.; Gutiérrez, M.; Alarcón-Herrera, M.T.; de Lourdes Villalba, M.; Deng, S. Occurrence and treatment of arsenic in groundwater and soil in northern Mexico and southwestern USA. Chemosphere 2011, 83, 211-225. [CrossRef]

10. Alexakis, D.E.; Bathrellos, G.D.; Skilodimou, H.D.; Gamvroula, D.E. Spatial distribution and evaluation of arsenic and zinc content in the soil of a karst landscape. Sustainability 2021, 13, 6976. [CrossRef]

11. Podgorski, J.; Berg, M. Global threat of arsenic in groundwater. Science 2020, 368, 845-850. [CrossRef]

12. Sarkar, A.; Paul, B. The global menace of arsenic and its conventional remediation-A critical review. Chemosphere 2016, 158, 37-49. [CrossRef] [PubMed]

13. Singh, S.K.; Stern, E.A. Global Arsenic Contamination: Living With the Poison Nectar. Environ. Sci. Policy Sustain. Dev. 2017, 59, 24-28. [CrossRef]

14. WHO (World Health Organization). Guidelines for Drinking-Water Quality, 4th ed.; WHO: Geneva, Switzerland, 2011; ISBN 978-92-4-154995-0. Available online: https:/ / www.who.int/publications/i/item/9789241549950 (accessed on 7 November 2021).

15. Nacional, E.; Unidos, E.; Secretaría, M.; Tuberculosis, D.E.L.A.; La, E.N.; Primaria, A.; Salud, A.L.A. MODIFICACION a la NORMA OFICIAL MEXICANA NOM-006-SSA2-1993, para la Prevención y. Ley Federal sobre Metrología y Normalización, se publicó en el Diario Oficial de la Federación el proyecto de la presente Norma Oficial Mexicana. 2000. Available online: https:/ / www.cndh.org.mx/DocTR/2016/JUR/A70/01/JUR-20170331-NOR39.pdf (accessed on 7 November 2021).

16. Jawadi, H.A.; Malistani, H.A.; Moheghy, M.A.; Sagin, J. Essential trace elements and arsenic in thermal springs, Afghanistan. Water 2021, 13, 134. [CrossRef]

17. Ahoulé, D.G.; Lalanne, F.; Mendret, J.; Brosillon, S.; Maïga, A.H. Arsenic in African Waters: A Review. Water Air Soil Pollut. 2015, 226, 302. [CrossRef]

18. Abiye, T.A.; Bhattacharya, P. Arsenic concentration in groundwater: Archetypal study from South Africa. Groundw. Sustain. Dev. 2019, 9, 100246. [CrossRef]

19. Khan, K.M.; Chakraborty, R.; Bundschuh, J.; Bhattacharya, P.; Parvez, F. Health effects of arsenic exposure in Latin America: An overview of the past eight years of research. Sci. Total Environ. 2020, 710, 136071. [CrossRef]

20. Rahman, M.A.; Hashem, M.A. Arsenic, iron and chloride in drinking water at primary school, Satkhira, Bangladesh. Phys. Chem. Earth 2019, 109, 49-58. [CrossRef]

21. Rahman, M.A.; Rahman, A.; Khan, M.Z.K.; Renzaho, A.M.N. Human health risks and socio-economic perspectives of arsenic exposure in Bangladesh: A scoping review. Ecotoxicol. Environ. Saf. 2018, 150, 335-343. [CrossRef]

22. Nickson, R.; McArthur, J.; Burgess, W.; Matin Ahmed, K.; Ravenscroft, P.; Rahman, M. Arsenic poisoning of Bangladesh groundwater. Nature 1998, 395, 338. [CrossRef]

23. Liu, F.F.; Wang, J.P.; Zheng, Y.J.; Ng, J.C. Biomarkers for the evaluation of population health status 16 years after the intervention of arsenic-contaminated groundwater in Xinjiang, China. J. Hazard. Mater. 2013, 262, 1159-1166. [CrossRef]

24. Golfinopoulos, S.K.; Varnavas, S.P.; Alexakis, D.E. The status of arsenic pollution in the greek and Cyprus environment: An overview. Water 2021, 13, 224. [CrossRef]

25. Katko, T.S.; Lipponen, M.A.; Rönkä, E.K.T. Groundwater use and policy in community water supply in Finland. Hydrogeol. J. 2006, 14, 69-78. [CrossRef]

26. Varsanyi, I. Arsenic in deep groundwater. In Proceedings of the 6th International Symposium on Water-Rock Interaction (WRI-6), Malvern, UK, 3-6 August 1989; pp. 715-718. 
27. Bhowmick, S.; Pramanik, S.; Singh, P.; Mondal, P.; Chatterjee, D.; Nriagu, J. Arsenic in groundwater of West Bengal, India: A review of human health risks and assessment of possible intervention options. Sci. Total Environ. 2018, 612, 148-169. [CrossRef] [PubMed]

28. Ghosh (Nath), S.; Debsarkar, A.; Dutta, A. Technology alternatives for decontamination of arsenic-rich groundwater-A critical review. Environ. Technol. Innov. 2019, 13, 277-303. [CrossRef]

29. Ortiz-Letechipia, J.; González-Trinidad, J.; Júnez-Ferreira, H.E.; Bautista-Capetillo, C.; Dávila-Hernández, S. Evaluation of groundwater quality for human consumption and irrigation in relation to arsenic concentration in flow systems in a semi-arid mexican region. Int. J. Environ. Res. Public Health 2021, 18, 8045. [CrossRef]

30. Avila-Sandoval, C.; Júnez-Ferreira, H.; González-Trinidad, J.; Bautista-Capetillo, C.; Pacheco-Guerrero, A.; Olmos-Trujillo, E. Spatio-Temporal Analysis of Natural and Anthropogenic Arsenic Sources in Groundwater Flow Systems. Int. J. Environ. Res. Public Health 2018, 15, 2374. [CrossRef]

31. Foust, R.D.; Mohapatra, P.; Compton-O'Brien, A.M.; Reifel, J. Groundwater arsenic in the Verde Valley in central Arizona, USA Appl. Geochem. 2004, 19, 251-255. [CrossRef]

32. Frost, F.; Franke, D.; Pierson, K.; Woodruff, L.; Raasina, B.; Davis, R.; Davies, J. A seasonal study of arsenic in groundwater, Snohomish County, Washington, USA. Environ. Geochem. Health 1993, 15, 209-214. [CrossRef]

33. Dehbandi, R.; Abbasnejad, A.; Karimi, Z.; Herath, I.; Bundschuh, J. Hydrogeochemical controls on arsenic mobility in an arid inland basin, Southeast of Iran: The role of alkaline conditions and salt water intrusion. Environ. Pollut. 2019, 249, 910-922 [CrossRef]

34. Aullón Alcaine, A.; Schulz, C.; Bundschuh, J.; Jacks, G.; Thunvik, R.; Gustafsson, J.P.; Mörth, C.M.; Sracek, O.; Ahmad, A.; Bhattacharya, P. Hydrogeochemical controls on the mobility of arsenic, fluoride and other geogenic co-contaminants in the shallow aquifers of northeastern La Pampa Province in Argentina. Sci. Total Environ. 2020, 715, 136671. [CrossRef]

35. Saravanan, K.; Srinivasamoorthy, K.; Prakash, R.; Gopinath, S.; Suma, C.S. An Evaluation of Hydrogeochemistry of Groundwater in Upper Vellar Sub-Basin Using Mineral Stability and Solute Transport Modelling. Aquat. Procedia 2015, 4, 1119-1125. [CrossRef]

36. Kammoun, S.; Trabelsi, R.; Re, V.; Zouari, K. Coastal aquifer salinization in semi-arid regions: The case of grombalia (Tunisia). Water 2021, 13, 129. [CrossRef]

37. Chebotarev, I.I. Metamorphism of natural waters in the crust of weathering-2. Geochim. Cosmochim. Acta 1955, 8, 137-170. [CrossRef]

38. Navarro, O.; González, J.; Júnez-Ferreira, H.E.; Bautista, C.-F.; Cardona, A. Correlation of Arsenic and Fluoride in the Groundwater for Human Consumption in a Semiarid Region of Mexico. Procedia Eng. 2017, 186, 333-340. [CrossRef]

39. Bundschuh, J.; Litter, M.; Ciminelli, V.S.T.; Morgada, M.E.; Cornejo, L.; Hoyos, S.G.; Hoinkis, J.; Alarcón-Herrera, M.T.; Armienta, M.A.; Bhattacharya, P. Emerging mitigation needs and sustainable options for solving the arsenic problems of rural and isolated urban areas in Latin America-A critical analysis. Water Res. 2010, 44, 5828-5845. [CrossRef]

40. Ferguson, J.F.; Gavis, J. A review of the arsenic cycle in natural waters. Water Res. 1972, 6, 1259-1274. [CrossRef]

41. Roh, T.; Lynch, C.F.; Weyer, P.; Wang, K.; Kelly, K.M.; Ludewig, G. Low-level arsenic exposure from drinking water is associated with prostate cancer in Iowa. Environ. Res. 2017, 159, 338-343. [CrossRef]

42. Gevaert, A.; Hoogesteger, J.; Stoof, C. Suitability of Using Groundwater Temperature and Geology to Predict ARSENIC Contamination in Drinking Water-A Case Study in Central Mexico; Internet-First University Press, 2012. Available online: https:/ / ecommons.cornell. edu/handle/1813/29590 (accessed on 7 November 2021).

43. Liu, Q.; Lu, X.; Peng, H.; Popowich, A.; Tao, J.; Uppal, J.S.; Yan, X.; Boe, D.; Le, X.C. Speciation of arsenic-A review of phenylarsenicals and related arsenic metabolites. TrAC-Trends Anal. Chem. 2018, 104, 171-182. [CrossRef]

44. U.S. EPA. 2010 U.S. Environmental Protection Agency (EPA) Decontamination Research and Development Conference; 2011; EPA/600/R-. Available online: https://cfpub.epa.gov/si/si_public_record_report.cfm?Lab=NHSRC\&dirEntryId=231764 (accessed on 7 November 2021).

45. Weerasundara, L.; Ok, Y.S.; Bundschuh, J. Selective removal of arsenic in water: A critical review. Environ. Pollut. 2021, 268, 115668. [CrossRef]

46. Planer-Friedrich, B.; Armienta, M.A.; Merkel, B.J. Origin of arsenic in the groundwater of the Rioverde basin, Mexico. Environ. Geol. 2001, 40, 1290-1298. [CrossRef]

47. Flora, S.J.S. Arsenic: Chemistry, Occurrence, and Exposure. In Handbook of Arsenic Toxicology; Academic Press: Cambridge, MA, USA, 2015; pp. 1-49. ISBN 9780124199552.

48. Fazi, S.; Amalfitano, S.; Casentini, B.; Davolos, D.; Pietrangeli, B.; Crognale, S.; Lotti, F.; Rossetti, S. Arsenic removal from naturally contaminated waters: A review of methods combining chemical and biological treatments. Rend. Lincei 2016, 27, 51-58. [CrossRef]

49. Cui, J.; Jing, C. A review of arsenic interfacial geochemistry in groundwater and the role of organic matter. Ecotoxicol. Environ. Saf. 2019, 183, 109500. [CrossRef] [PubMed]

50. Maier, M.V.; Isenbeck-Schröter, M.; Klose, L.B.; Ritter, S.M.; Scholz, C. In Situ-mobilization of Arsenic in Groundwater-An Innovative Remediation Approach? Procedia Earth Planet. Sci. 2017, 17, 452-455. [CrossRef]

51. THE 17 GOALS I Sustainable Development. Available online: https://sdgs.un.org/goals (accessed on 7 November 2021).

52. Comisión Nacional del Agua Actualización de la disponibilidad media anual de agua en el acuífero Calera (3225), estado de Zacatecas. D. Of. La Fed. 2018, pp. 1-39. Available online: https://sigagis.conagua.gob.mx/gas1/Edos_Acuiferos_18/zacatecas/ DR_3225.pdf (accessed on 7 November 2021). 
53. INEGI. Sintesis geográfica de Zacatecas. 1981. Available online: http://internet.contenidos.inegi.org.mx/contenidos/productos/prod_ serv/contenidos/espanol/bvinegi/productos/historicos/2104/702825220686/702825220686_3.pdf (accessed on 7 November 2021).

54. Gandullo, J.M. Edaphology, ecology and reforestation [Spanish]. Ecologia 1990, 128-138. Available online: https://agris.fao.org/ agris-search/search.do? recordID=ES9100328 (accessed on 7 November 2021).

55. Lenore, S.; Clesceri, A.; Greenberg, E.; Trussel, R.R. Standard Methods for the Examination of Water and Wastewater, 20th ed.; American Public Health Association: Washington, DC, USA, 2006.

56. Oliver, M.A.; Webster, R. Kriging: A method of interpolation for geographical information systems. Int. J. Geogr. Inf. Syst. 1990, 4 313-332. [CrossRef]

57. Chirinos, L.R.; Mallqui, C.G. Comparación entre Interpoladores Espaciales en el Estudio de Distribución de Partículas Sedimentables Insolubles en la Cuenca Atmosférica de Lima y Callao. Inf. Tecnológica 2016, 27, 111-120. [CrossRef]

58. Parkhurst, D.L.; Appelo, C.A.J. User's Guide to PHREEQC (Version 2): A Computer Program for Speciation, Batch-Reaction, OneDimensional Transport, and Inverse Geochemical Calculations; USGS Publications Warehouse: Menlo Park, CA, USA, 1999.

59. Daintith, J. (Ed.) A Dictionary of Chemistry, 6th ed.; Oxford University Press: Oxford, UK, 2008; ISBN 9780199204632.

60. Liu, J.-L.; Li, C.-L. A generalized Debye-Hückel theory of electrolyte solutions. AIP Adv. 2019, 9, 015214. [CrossRef]

61. Thyne, G. Review of PHREEQC. • Southwest Hydrol. • 37. Available online: https://igwmc.mines.edu/ (accessed on 7 November 2021).

62. Toran, L.; Grandstaff, D. PHREEQC and PHREEQCI: Geochemical Modeling with an Interactive Interface. Ground Water 2002, 40, 462-464. [CrossRef]

63. Liu, C.W.; Wu, M.Z. Geochemical, mineralogical and statistical characteristics of arsenic in groundwater of the Lanyang Plain, Taiwan. J. Hydrol. 2019, 577, 123975. [CrossRef]

64. Unger-Shayesteh, K.; Vorogushyn, S.; Farinotti, D.; Gafurov, A.; Duethmann, D.; Mandychev, A.; Merz, B. What do we know about past changes in the water cycle of Central Asian headwaters? A review. Glob. Planet. Change 2013, 110, 4-25. [CrossRef]

65. Mitra, A.; Chatterjee, S.; Gupta, D.K. Environmental Arsenic Exposure and Human Health Risk; Springer: Cham, Switzerland, 2020; pp. 103-129. [CrossRef]

66. Basu, A.; Saha, D.; Saha, R.; Ghosh, T.; Saha, B. A review on sources, toxicity and remediation technologies for removing arsenic from drinking water. Res. Chem. Intermed. 2014, 40, 447-485. [CrossRef]

67. Malyan, S.K.; Singh, R.; Rawat, M.; Kumar, M.; Pugazhendhi, A.; Kumar, A.; Kumar, V.; Kumar, S.S. An overview of carcinogenic pollutants in groundwater of India. Biocatal. Agric. Biotechnol. 2019, 21, 101288. [CrossRef]

68. Smith, A.H.; Hopenhayn-Rich, C.; Bates, M.N.; Goeden, H.M.; Hertz-Picciotto, I.; Duggan, H.M.; Wood, R.; Kosnett, M.J.; Smith, M.T. Cancer risks from arsenic in drinking water. Environ. Health Perspect. 1992, 97, 259-267. [CrossRef] [PubMed]

69. Faria, M.C.S.; Rosemberg, R.S.; Bomfeti, C.A.; Monteiro, D.S.; Barbosa, F.; Oliveira, L.C.A.; Rodriguez, M.; Pereira, M.C.; Rodrigues, J.L. Arsenic removal from contaminated water by ultrafine $\delta$-FeOOH adsorbents. Chem. Eng. J. 2014, $237,47-54$. [CrossRef]

70. Jageerani, S. Review: Arsenic Remediation by Synthetic and Natural Adsorbents. Pak. J. Anal. Environ. Chem. 2017, 18, 18-36. [CrossRef]

71. Fu, D.; Kurniawan, T.A.; Li, H.; Wang, H.; Wang, Y.; Li, Q. Co-oxidative removal of arsenite and tetracycline based on a heterogeneous Fenton-like reaction using iron nanoparticles-impregnated biochar. Environ. Pollut. 2021, 290, 118062. [CrossRef] [PubMed]

72. Fu, D.; Kurniawan, T.A.; Lin, L.; Li, Y.; Avtar, R.; Dzarfan Othman, M.H.; Li, F. Arsenic removal in aqueous solutions using FeS2. J. Environ. Manag. 2021, 286, 112246. [CrossRef]

73. Freeze, A.; Cherry, J. Groundwater: Englewood Cliffs, Chapter 7_ Chemical Evolution of Natural Groundwater _ HWB. In Groundwater; Prentice-Hall Inc.: Englewood Cliffs, NJ, USA, 1979. Available online: http:/ /hydrogeologistswithoutborders.org/ wordpress/1979-english/chapter-7/ (accessed on 7 November 2021).

74. Pujades, E.; Jurado, A. Groundwater-related aspects during the development of deep excavations below the water table: A short review. Undergr. Sp. 2019, 6, 35-45. [CrossRef]

75. Bhattacharya, P.; Polya, D.; Jovanovic, D. (Eds.) Best Practice Guide on the Control of Arsenic in Drinking Water; IWA Publishing: London, UK, 2017; ISBN 9781780404929.

76. Mohan, D.; Pittman, C.U. Arsenic removal from water/wastewater using adsorbents-A critical review. J. Hazard. Mater. 2007, 142, 1-53. [CrossRef]

77. Alarcón-Herrera, M.T.; Martin-Alarcon, D.A.; Gutiérrez, M.; Reynoso-Cuevas, L.; Martín-Domínguez, A.; Olmos-Márquez, M.A.; Bundschuh, J. Co-occurrence, possible origin, and health-risk assessment of arsenic and fluoride in drinking water sources in Mexico: Geographical data visualization. Sci. Total Environ. 2020, 698, 134168. [CrossRef]

78. Pearson, K. VII. Mathematical contributions to the theory of evolution.-III. Regression, heredity, and panmixia. Philos. Trans. R. Soc. London 1896, 187, 253-318. [CrossRef]

79. Rosales-Rivera, M.; Díaz-González, L.; Verma, S.P. A new online computer program (BiDASys) for ordinary and uncertainty weighted least-squares linear regressions: Case studies from food chemistry. Rev. Mex. Ing. Quim. 2018, 17, 507-522. [CrossRef]

80. López-Guzmán, M.; Alarcón-Herrera, M.T.; Irigoyen-Campuzano, J.R.; Torres-Castañón, L.A.; Reynoso-Cuevas, L. Simultaneous removal of fluoride and arsenic from well water by electrocoagulation. Sci. Total Environ. 2019, 678, 181-187. [CrossRef] [PubMed] 
81. Zhao, X.; Guo, H.; Wang, Y.; Wang, G.; Wang, H.; Zang, X.; Zhu, J. Groundwater hydrogeochemical characteristics and quality suitability assessment for irrigation and drinking purposes in an agricultural region of the North China plain. Environ. Earth Sci. 2021, 80, 162. [CrossRef]

82. Martínez-Acuña, M.I.; Mercado-Reyes, M.; Alegría-Torres, J.A.; Mejía-Saavedra, J.J. Preliminary human health risk assessment of arsenic and fluoride in tap water from Zacatecas, México. Environ. Monit. Assess. 2016, 188, 476. [CrossRef] [PubMed]

83. Thakur, L.S.; Mondal, P. Simultaneous arsenic and fluoride removal from synthetic and real groundwater by electrocoagulation process: Parametric and cost evaluation. J. Environ. Manag. 2017, 190, 102-112. [CrossRef]

84. Narasaiah, V.; Rao, B.V. Groundwater quality of an hard rock aquifer in the Subledu Basin of Khammam district, India. Appl. Water Sci. 2021, 11, 89. [CrossRef] 